\title{
Smoking and SARS-CoV-2: Are Polish health professionals at higher risk of infection?
}

\author{
Paweł Koczkodaj', Magdalena Cedzyńska', Joanna Didkowska'
}

\section{Dear Editor,}

In Poland about $26 \%$ of adults smoke cigarettes, $31 \%$ of males (regular smokers $26 \%$ ) and $21 \%$ of females (regular smokers $17 \%$ ). The highest smoking prevalence is most pronounced among people aged $45-54$ years (35\%) and 55-64 years (32\%), the lowest rates are observed among young adults aged 18-24 years. Moreover, within the last years, the decrease in smoking prevalence in Poland is due mainly to the lower number of smokers among males, currently about 9 percentage points (pp) less in comparison with 2012. In women, the drop was more modest at about $2 \mathrm{pp}$ since $2012^{1}$.

The smoking patterns may demonstrate an accelerating potential for further pandemic development in Poland. There is more and more evidence showing a significant correlation between smoking and higher risk of SARS-CoV-2 infection and COVID-19 development ${ }^{2,3}$. As mentioned, in Poland smoking prevalence is higher among the older age groups. Similarly, the risk of a severe course of COVID-19 increases with age ${ }^{4}$. These overlapping strong risk factors may be of crucial importance for the Polish general population, but notably for health professionals in Poland. The age structure of particular professional groups (Figure 1) is associated with higher risk of exposure in daily work as well as with potential smoking patterns that may result in drastic consequences for the healthcare system, where staff shortages are already severe.

Collected data show that the great majority of health professionals in Poland represent older age groups than younger ones, especially in the case of nurses and medical doctors. Smoking in this particular cohort can be considered as a potential

\section{AFFILIATION \\ 1 Cancer Epidemiology and Primary Prevention Department, Maria Sklodowska-Curie National Research Institute of Oncology, Warsaw, Poland. \\ CORRESPONDENCE TO Paweł Koczkodaj. Cancer Epidemiology and Primary Prevention Department, Maria Sklodowska-Curie National Research Institute of Oncology, Wawelska Street 15B, 02-034, Warsaw, Poland. E-mail: pawel.koczkodaj@ nio-pib.pl}

\section{KEYWORDS}

Poland, smoking, health professionals, coronavirus, COVID-19

Received: 18 May 2020 Revised: 21 May 2020 Accepted: 22 May 2020

Figure 1. Percentage of nurses, midwives ${ }^{*}$, medical doctors and dentists ${ }^{* *}$ in Poland by age group

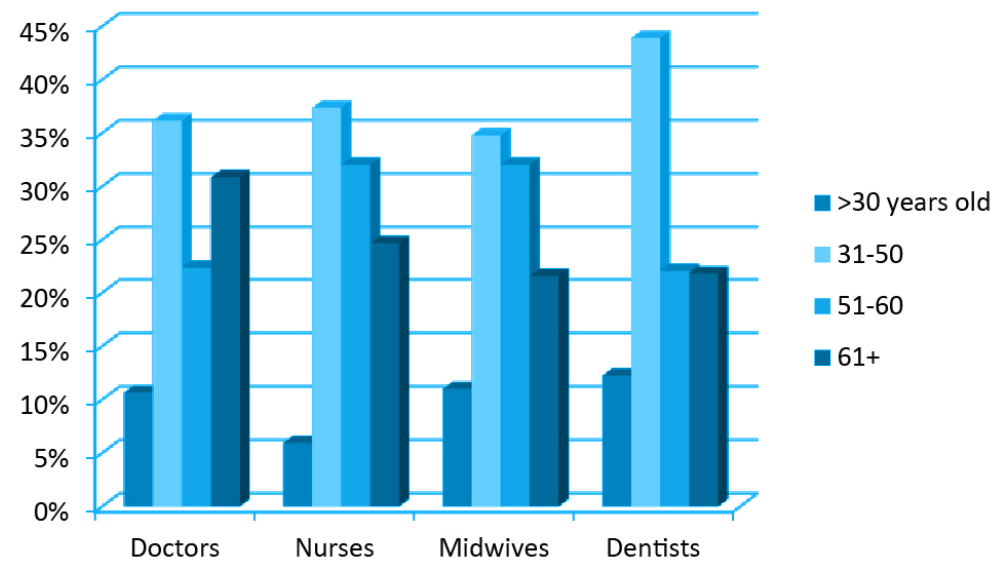

*Data from 31 December 2018 sourced from the Chamber of Nurses and Midwives in Poland. ${ }^{* *}$ Data from 4 May 2020 sourced from the Supreme Medical Chamber in Poland. 
threat for a further increase in the number of health professionals that are excluded from the healthcare system due to COVID-19 treatment and quarantine (in April 2020 there were about 4500 health professionals in quarantine ${ }^{5}$ ). Unfortunately, the data on smoking prevalence among Polish health professionals are very limited. There are a few studies presenting percentages of medical doctors, dentists, nurses and midwives who smoke (investigated groups were small and careful inference is recommended). For example, a study conducted in $2018^{6}$ (cohort of 423 physicians) showed that $7.8 \%$ of respondents were current smokers. Another study ${ }^{7}$ indicated that among 544 investigated dentists $13.2 \%$ were current smokers. On the other hand, Adamek et al. ${ }^{8}$ showed in their study that $40 \%$ of nurses smoked cigarettes.

Despite many limitations, the above data indicate that smoking is still a real health problem among health professionals, which nowadays has another important meaning. Even though the discussed data are very scarce, there is also other evidence showing that stress is a significant risk factor for smoking ${ }^{9}$ that may explain the higher smoking prevalence among health professionals.

In view of the above data and current epidemiological circumstances, we suggest to include recommendations on the importance of smoking cessation among health professionals to the national coronavirus medical guidance as well as to existing and future coronavirus public health campaigns.

\section{REFERENCES}

1. Centrum Badania Opinii Społecznej. Palenie papierosów [Smoking]. Nr 104/2019. ISSN 2353-5822. https://cbos.pl/ SPISKOM.POL/2019/K_104_19.PDF. Published August, 2019. Accessed May 18, 2020.

2. Vardavas CI, Nikitara K. COVID-19 and smoking: A systematic review of the evidence. Tob Induc Dis. 2020;18(March). doi:10.18332/tid/119324

3. Emami A, Javanmardi F, Pirbonyeh N, Akbari A. Prevalence of Underlying Diseases in Hospitalized Patients with COVID-19: a Systematic Review and Meta-Analysis. Arch Acad Emerg Med. 2020;8(1):e35. PMID:32232218

4. Yao Q, Wang P, Wang X, et al. Retrospective study of risk factors for severe SARS-Cov-2 infections in hospitalized adult patients. Pol Arch Intern Med. 2020. doi:10.20452/pamw.15312

5. Polish Chief Sanitary Inspectorate's Spokesperson Statement - Medycyna Praktyczna. Niemal co piąty zakażony to pracownik medyczny [Almost every fifth infected is a medical worker]. https://www.mp.pl/pacjent/choroby-zakazne/ koronawirus/koronawirus-aktualnosci/232189,niemal-co-piaty-zakazony-to-pracownik-medyczny. Accessed May 12, 2020 .

6. Jankowski M, Kaleta D, Zgliczyński WS, et al. Cigarette and E-Cigarette Use and Smoking Cessation Practices among Physicians in Poland. Int J Environ Res Public Health. 2019;16(19):3595. doi:10.3390/ijerph16193595

7. Konopka T, Lella A, Stankiewicz-Szałapska A, Zapała J. Tobacco smoking among dentists in Poland. Polish Annals of Medicine. 2017;24(1):24-30 doi:10.1016/j.poamed.2016.08.002

8. Adamek R, Stoczyńska J, Maksymiuk T, et al. [Prevalence of tobacco smoking among nurses and the awareness of harmfulness of smoking habit]. Przegl Lek. 2012;69(10):969-972. PMID:23421072

9. Lawless MH, Harrison KA, Grandits GA, Eberly LE, Allen SS. Perceived stress and smoking-related behaviors and symptomatology in male and female smokers. Addict Behav. 2015;51:80-83. doi:10.1016/j.addbeh.2015.07.011

CONFLICTS OF INTEREST

The authors have completed and submitted the ICMJE Form for Disclosure of Potential Conflicts of Interest and none was reported.

FUNDING

There was no source of funding for this research. 